\title{
The influence of simvastatin in induced peritoneal fibrosis in rats by peritoneal dialysis solution with glucosis $4.25 \%^{1}$
}

\author{
Influência da sinvastatina na fibrose peritoneal induzida em ratos pelo uso de solução de diálise \\ peritoneal com glicose a $4,25 \%$
}

\begin{abstract}
Gilberto Baroni', Adriana Fátima Menegat Schuinski" ${ }^{\text {II }}$ Poliana Turmena Berticelli"II, Maria Angélica Alexandre da Silva ${ }^{\mathrm{III}}$, Denise Sbrissia e Silva Gouveia ${ }^{I V}$, Roberto Pecoits Filhov', Fernando Meyer ${ }^{\mathrm{VI}}$

${ }^{\mathrm{I}} \mathrm{MD}$, Assistant Professor, Internal Medicine, State University of Ponta Grossa. Fellow Master degree in Surgery, PUCPR, Curitiba-PR, Brazil. Main author. Conception, design, manuscript writing.

IIMD, Assistant Professor, Internal Medicine, State University of Ponta Grossa. Fellow Master degree in Surgery, PUCPR, Curitiba-PR, Brazil. Acquisition of data, manuscript writing.

III Graduate student, Medical School, PUCPR, Curitiba-PR, Brazil. Helped with technical procedures.

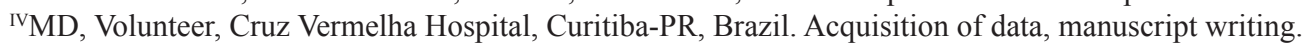

${ }^{\mathrm{v}} \mathrm{PhD}$, Department of Nephrology, PUCPR, Curitiba-PR, Brazil. Design of the study.

${ }^{V} \mathrm{PhD}$, Chairman Full Professor, Urology Division, PUCPR, Head Department of Urology, Cajuru University Hospital, PUCPR, Curitiba-PR, Brazil. Conception and design of the study, critical revision. Tutor.
\end{abstract}

\begin{abstract}
PURPOSE: To investigate the influence of using simvastatin on the peritoneal fibrosis induced in rats using peritoneal dialysis solution with glucoses $4.25 \%$.

METHODS: Prospective controlled study in 20 non-uremic Wistar rats. The animals received a peritoneal infusion of $10 \mathrm{ml} / 100 \mathrm{~g}$ of peritoneal dialysis solution glucose $4.25 \%$ on a daily basis. The animals were divided in two groups: experimental and control. The experimental group received simvastatin $4 \mathrm{mg} / \mathrm{kg} / \mathrm{d}$, by a gastric tube. The control group did not receive any drug. The follow-up was 21 and 49 days. At the end, one surgical procedure was performed to get histological samples of visceral and parietal peritoneum. The samples were analyzed using Hematoxylin Eosin and Sirius Red, to evaluate the severity of the fibrosis.

RESULTS: The analysis showed that the intensity of the fibrosis, the peritoneal thickness and the cell number in experimental and control groups were not statistically significant different in experimental and control groups.

CONCLUSION: The simvastatin do not decrease the intensity of fibrosis on the peritoneal membrane that happens on rats on peritoneal dialysis.
\end{abstract}

Key words: Peritoneal Fibrosis. Peritoneal Dialysis. Simvastatin. Rats.

\section{RESUMO}

OBJETIVO: Investigar a influência do uso da sinvastatina na fibrose peritoneal induzida em ratos pelo uso de solução de diálise peritoneal rica em glicose.

MÉTODOS: Estudo prospectivo controlado, em ratos Wistar não urêmicos. Foram estudados 20 animais. Os animais foram submetidos diariamente à punção abdominal, sendo infundida solução de diálise peritoneal com glicose a 4,25\% na dose de $10 \mathrm{ml} / 100 \mathrm{~g}$ de peso. Os animais foram divididos em dois grupos: experimental e controle. O grupo experimental recebeu sinvastatina na dose de $4 \mathrm{mg} / \mathrm{kg} / \mathrm{dia}$ por gavagem. O grupo controle não recebeu nenhuma droga. Foram acompanhados por 21 e 49 dias. Ao final do período foram submetidos à procedimento cirúrgico para retirada de peritônio parietal e visceral. As amostras obtidas foram analisadas histologicamente, usando-se coloração Hematoxilina - Eosina e Sirius Red, para avaliação do grau de fibrose.

RESULTADOS: A análise mostrou que a intensidade da fibrose, a espessura do peritônio e o número de células não atingiram diferença estatisticamente significante entre os grupos experimental e controle.

CONCLUSÃO: A sinvastatina não foi capaz de alterar a intensidade da fibrose peritoneal induzida pelo uso de solução de diálise em ratos.

Descritores: Fibrose Peritoneal. Diálise Peritoneal. Sinvastatina. Ratos. 


\section{Introduction}

Chronic kidney disease (CKD) is defined as the progressive and irreversible loss of kidney function (glomerular, tubular and endocrine). In its most advanced stage (called endstage chronic renal failure - CRF), the kidneys can no longer maintain the normal internal environment of the patient, requiring the institution of renal replacement therapy ${ }^{1}$.

Peritoneal dialysis (PD) has become popular after the introduction of continuous ambulatory peritoneal dialysis (CAPD). The CAPD is done at home, cause a smaller impact on the social life of patients, providing a survival equivalent to that offered by hemodialysis ${ }^{2}$, but the occurrence of peritonitis and peritoneal fibrosis, which may progress to encapsulating peritonitis, still limit CAPD.

An Australian study showed that the risk of developing encapsulating peritonitis is increasing as the patient stay in PD, reaching a prevalence of $19.4 \%$ in patients treated for more than eight years ${ }^{3}$. A Scottish study, also showed that the incidence of encapsulating peritonitis increases with time on $\mathrm{PD}^{4}$. Peritoneal fibrosis, which occurs in PD patients, has a complex pathophysiology, with several factors that lead to this situation, including uremia itself, the episodes of peritonitis, and PD solution.

Given the importance of the issue, were developed experimental models to study the mechanism of fibrosis, changes in the intensity by using drug. Ishii et al..$^{5}$ developed a model in mice using intraperitoneal injection of chlorhexidine gluconate $0.1 \%$ and $15 \%$ ethanol dissolved in saline at a dose of $0.3 \mathrm{ml}$ daily, using buffered saline in the control group. The animals were followed for 56 days. All animals in the group that used chlorhexidine and alcohol 18 developed encapsulating peritonitis ${ }^{5}$. However these models, although induce inflammation and fibrosis, differ substantially from what happens to patients.

Bui et al. ${ }^{6}$ used the infusion of hypertonic PD solution to study the capacity of $\mathrm{N}$-acetylcysteine protect the peritoneum from the harmful action of PD solution. They concluded that the use of PD solution with $3.86 \%$ glucose induces significant changes in the peritoneum, and that the use of $\mathrm{N}$-acetylcysteine had a protective effect.

Statins can be used to modify the course of various diseases due to their anti-inflammatory properties, but there are few data regarding its use in preventing peritoneal fibrosis.

\section{Methods}

The experiment carried out was submitted to the Ethics Committee on Animal Use of the Pontifical Catholic University of Parana.

It was an experimental, prospective, controlled study. Twenty male rats (Rattus norvegicus) Wistar, 90 days old, not uremic, weighing 249 to $320 \mathrm{~g}$ were studied. They were divided into two groups, experimental and control, each one with ten individuals. They were kept in standardized boxes, with a maximum of five rats per box, at a temperature of $21^{\circ} \pm 2$, controlled lighting, with light/dark cycle of 12 hours. The animals were marked and placed in cages with free access to water and food. They were evaluated daily and weighed.

All rats were subjected daily to abdominal puncture in the left lower quadrant, using straight-type needle size 25 x 7 . It was infused peritoneal dialysis solution commercially available, produced by Baxter Hospitalar Ltda ${ }^{\circledR}$, with a glucose concentration of $4.25 \%$, buffered with lactate. The dose infused was $10 \mathrm{ml}$ per $100 \mathrm{~g}$ of body weight. Ten animals were followed for 21 days, and ten for 49 days. The sample was divided into two groups of ten as follows: Experimental group: received a daily dose of $2 \mathrm{mg} / \mathrm{kg}$ bid of simvastatin, by gavage. This solution, containing simvastatin at a concentration of $1 \mathrm{mg} / \mathrm{ml}$ was prepared in the pharmacy of the PUCPR, being composed of saccharin sodium, aerosil and sweet almond oil. A steel tube, curved, with blunt tips, measuring $8 \mathrm{~cm}$ in length, outside diameter of $1.5 \mathrm{~mm}$, produced by Micof ${ }^{\circledR} \mathrm{DL}$ Company, was used to perform the gavage,. Control group: did not receive simvastatin.

On 21 and 49, five animals in the control group and five in the experimental group were analyzed. The animals were anesthetized with ketamine and xilasine, both intramuscular. A surgical procedure was performed. The spleen was removed for analysis of the visceral peritoneum, and abdominal wall from the right upper quadrant was removed for histological analysis of the parietal peritoneum. Euthanasia was performed with lethal dose of anesthetic drug. The abdominal wall and spleen were sent for histological analysis at the Laboratory of Experimental Pathology PUCPR. The material was prepared in paraffin with five microns in thick. Were used hematoxylin - eosin (HE) and Sirius Red stain. The pathologist analyzed the samples blindly. It was used Olympus ${ }^{\circledR}$ Bx 50 microscope. To capture the images was used a Sony ${ }^{\circledR}$ CCD101 camera, they were transferred to a Sony ( Trinitron color monitor. The images were analyzed using the Image Plus ${ }^{\circledR} 4.5$ for Windows ${ }^{\circledR}$ MediaCybernetics. The thickness of the peritoneum parietal and the visceral were measured. In each 
slide ten histological fields were chosen, and each field were taken ten measurements. The amount of collagen types I and III was measured in an automated fashion using Sirius Red staining. The number of mesothelial cells per field was counted.

The results obtained in the study were expressed as mean, standard deviation, median, minimum and maximum values. To compare the groups, it was used the nonparametric Mann-Whitney test. P values $<0.05$ were considered statistically significant. Data were analyzed with the computer program Statistical v.8.0.

\section{Results}

Five animals died during the follow-up. At the end of the experiment, the sample was: control group 21 days - three animals, control group 49 days - five animals, experimental group 21 days - four animals, experimental group 49 days - three animals. No other major complications occurred. During the experimental period the animals gained weight, and there was no statistically significant differences between control and experimental groups.

There was thickening of peritoneum parietal, as demonstrated in Table 1.

TABLE 1 - Parietal peritoneum thickness $(\mu \mathrm{m})$ for 21 days, control and experimental groups.

\begin{tabular}{ccccccc}
\hline Group & Mean & Median & Minimum Maximum & $\begin{array}{c}\text { Standard } \\
\text { deviation }\end{array}$ & $p$ value \\
\hline Control & 84.2 & 88.0 & 68.2 & 96.5 & 14.6 & \\
Experimental & 74.7 & 72.3 & 55.8 & 98.6 & 19.3 & 0.629 \\
\hline
\end{tabular}

It was realized that the thickening was even bigger when you complete the period of 49 days. The difference of thickness of peritoneum between the control group and the experiment was greater than in 21 days, although without achieving statistical significance $(\mathrm{p}=0.229)$ (Table 2$)$.

TABLE 2 - Parietal peritoneum thickness ( $\mu \mathrm{m}) 49$ days, control and experimental groups.

\begin{tabular}{ccccccc}
\hline Group & Mean & Median & Minimum & Maximum & $\begin{array}{c}\text { Standard } \\
\text { deviation }\end{array}$ & p value \\
\hline Control & 96.6 & 94.2 & 76.5 & 121.4 & 18.5 & \\
Experimental & 78.1 & 77.3 & 71.9 & 85.1 & 6.6 & 0.229 \\
\hline
\end{tabular}

Compared the thicknesses between groups 21 and 49 days, one realizes that there was an intensification of thickening of peritoneum parietal, although without showing significant difference (Table 3).
TABLE 3 - Parietal peritoneum thickness $(\mu \mathrm{m}) 21$ and 49 days, control and experimental groups.

\begin{tabular}{cccc}
\hline Group & 21 & 49 & $\mathrm{p}$ value \\
\hline Control & 84.2 & 96.6 & 0.629 \\
\hline Experimental & 74.7 & 78.1 & 0.857 \\
\hline
\end{tabular}

In visceral peritoneum there was thickening also, although in much less degree than the parietal peritoneum. At 21 days the intensity of the fibrosis was greater in animals of the experiment, although without difference statistically significant (Table 4).

TABLE 4 - Visceral peritoneum thickness $(\mu \mathrm{m}) 21$ days, control and experimental groups.

\begin{tabular}{ccccccc}
\hline Group & Mean & Median & Minimum & Maximum & $\begin{array}{c}\text { Standard } \\
\text { deviation }\end{array}$ & p value \\
\hline C & 14.7 & 15.8 & 10.8 & 17.4 & 3.5 & \\
E & 19.7 & 19.8 & 15.7 & 23.7 & 3.3 & 0.229 \\
\hline
\end{tabular}

In animals followed by 49 days, the thickness of the visceral peritoneum was greater in the control group, but without reaching statistical significance (Table 5).

TABLE 5 - Visceral peritoneum thickness $(\mu \mathrm{m}) 49$ days, control and experimental groups.

\begin{tabular}{ccccccc}
\hline Group & Mean & Median & Minimum & Maximum & $\begin{array}{c}\text { Standard } \\
\text { deviation }\end{array}$ & p value \\
\hline C & 26.7 & 24.4 & 20.5 & 37.5 & 8.1 & \\
E & 20.8 & 21.7 & 13.9 & 26.9 & 6.5 & 0.629 \\
\hline
\end{tabular}

Comparing the thickness of the peritoneum at 21 and 49 days, we realized that there was progressive increasing, but without achieving significant statistically difference (Table 6).

TABLE 6 - Visceral peritoneum thickness $(\mu \mathrm{m}) 21$ and 49 days.

\begin{tabular}{cccc}
\hline Group & 21 & 49 & $\mathrm{p}$ value \\
\hline C & 14.7 & 26.7 & 0.057 \\
E & 19.7 & 20.8 & 0.857 \\
\hline
\end{tabular}


The results of counting the number of cells in the parietal peritoneum at 21 and 49 days, are shown in Tables 7 and 8 . It is clear that the number of cells is small in the experimental group, but did not reach statistical significance.

TABLE 7 - Number of cells in the parietal peritoneum (21 days), control and experimental groups.

\begin{tabular}{ccccccc}
\hline Group & Mean & Median & Minimum & Maximum & $\begin{array}{c}\text { Standard } \\
\text { deviation }\end{array}$ & p value \\
\hline C & 23.1 & 19.8 & 12.3 & 37.3 & 12.8 & \\
E & 14.7 & 12.4 & 7.1 & 26.8 & 8.6 & 0.4 \\
\hline
\end{tabular}

TABLE 8 - Number of cells in the parietal peritoneum (49 days), control and experimental groups.

\begin{tabular}{ccccccc}
\hline Group & Mean & Median & Minimum & Maximum & $\begin{array}{c}\text { Standard } \\
\text { deviation }\end{array}$ & p value \\
\hline C & 24.2 & 21.7 & 15.1 & 34.6 & 7.6 & \\
E & 16.0 & 14.0 & 9.4 & 24.6 & 7.8 & 0.25 \\
\hline
\end{tabular}

The results of the count of the number of cells in the visceral peritoneum, 21 and 49 days, are shown in Tables 9 and 10. The number of cells is greater in the experimental group at 21 days, but without statistical significance.

TABLE 9 - Visceral peritoneum cell count (21 days), control and experimental groups.

\begin{tabular}{ccccccc}
\hline Group & Mean & Median & Minimum & Maximum & $\begin{array}{c}\text { Standard } \\
\text { deviation }\end{array}$ & p value \\
\hline C & 18.6 & 23.1 & 6.6 & 26.1 & 10.5 & \\
E & 25.8 & 25.2 & 20.4 & 32.4 & 5.1 & 0.4 \\
\hline
\end{tabular}

TABLE 10 - Visceral peritoneum cell count (49 days), control and experimental groups.

\begin{tabular}{ccccccc}
\hline Group & Mean & Median & Minimum & Maximum & $\begin{array}{c}\text { Standard } \\
\text { deviation }\end{array}$ & p value \\
\hline C & 31.7 & 27.7 & 22.1 & 45.4 & 9.1 & \\
E & 26.8 & 20.9 & 20.8 & 38.7 & 10.3 & 0.393 \\
\hline
\end{tabular}

The analysis of the degree of fibrosis and the quantity of collagen type I in the abdominal wall at 21 and 49 days, are shown in Tables 11 and 12. The amount of collagen type I in the parietal peritoneum is much lower in the experimental group at 21 days, but without statistically significant difference.

TABLE 11 - Collagen type I in parietal peritoneum (21 days), control and experimental groups.

\begin{tabular}{ccccccc}
\hline Group & Mean & Median & Minimum & Maximum & $\begin{array}{c}\text { Standard } \\
\text { deviation }\end{array}$ & p value \\
\hline C & 17.1 & 15.8 & 13.3 & 22.3 & 4.7 & \\
E & 9.1 & 8.6 & 7.6 & 11.6 & 1.8 & 0.057 \\
\hline
\end{tabular}

TABLE 12 - Collagen type I in parietal peritoneum (49 days), control and experimental groups.

\begin{tabular}{ccccccc}
\hline Group & Mean & Median & Minimum & Maximum & $\begin{array}{c}\text { Standard } \\
\text { deviation }\end{array}$ & p value \\
\hline C & 11.6 & 11.9 & 7.1 & 19.2 & 4.8 & \\
E & 11.5 & 12.1 & 7.3 & 15.3 & 4 & 1 \\
\hline
\end{tabular}

The quantities of collagen type $\mathrm{I}$ in the visceral peritoneum at 21 and 49 days are shown in Tables 13 and 14

TABLE 13 - Collagen type I in visceral peritoneum (21 days), control and experimental groups.

\begin{tabular}{ccccccc}
\hline Group & Mean & Median & Minimum & Maximum & $\begin{array}{c}\text { Standard } \\
\text { deviation }\end{array}$ & p value \\
\hline C & 12.8 & 14.4 & 6.6 & 17.4 & 5.6 & \\
E & 10.8 & 10.3 & 8.7 & 13.9 & 2.3 & 0.629 \\
\hline
\end{tabular}

TABLE 14 - Collagen type I in visceral peritoneum (49 days), control and experimental groups.

\begin{tabular}{ccccccc}
\hline Group & Mean & Median & Minimum & Maximum & $\begin{array}{c}\text { Standard } \\
\text { deviation }\end{array}$ & p value \\
\hline C & 10.8 & 11.6 & 8.4 & 13.2 & 2.1 & \\
E & 16.2 & 14.4 & 13.8 & 20.5 & 3.7 & 0.036 \\
\hline
\end{tabular}

The quantities of type III collagen in the parietal peritoneum are shown in Tables 15 and 16. 
TABLE 15 - Collagen type III in parietal peritoneum (21 days), control and experimental groups.

\begin{tabular}{ccccccc}
\hline Group & Mean & Median & Minimum & Maximum & $\begin{array}{c}\text { Standard } \\
\text { deviation }\end{array}$ & p value \\
\hline C & 17.3 & 15.5 & 14.4 & 22 & 4.1 & \\
E & 12.1 & 13.1 & 7.2 & 15.1 & 3.6 & 0.229 \\
\hline
\end{tabular}

TABLE 16 - Collagen type III in parietal peritoneum (49 days), control and experimental groups.

\begin{tabular}{ccccccc}
\hline Group & Mean & Median & Minimum & Maximum & $\begin{array}{c}\text { Standard } \\
\text { deviation }\end{array}$ & p value \\
\hline C & 17.6 & 15.3 & 9.8 & 36.8 & 11.1 & \\
E & 15.3 & 15.9 & 14.1 & 16 & 1.1 & 0.571 \\
\hline
\end{tabular}

The quantities of type III collagen in the visceral peritoneum are shown in Tables 17 and 18.

TABLE 17 - Collagen type III in visceral peritoneum visceral (21 days), control and experimental groups.

\begin{tabular}{ccccccc}
\hline Group & Mean & Median & Minimum & Maximum & $\begin{array}{c}\text { Standard } \\
\text { deviation }\end{array}$ & p value \\
\hline C & 13.1 & 12.8 & 9.5 & 16.9 & 3.7 & \\
E & 13.3 & 12.3 & 11.8 & 16.7 & 2.3 & 0.857 \\
\hline
\end{tabular}

TABLE 18 - Collagen type III in visceral peritoneum (49 days), control and experimental groups.

\begin{tabular}{ccccccc}
\hline Group & Mean & Median & Minimum & Maximum & $\begin{array}{c}\text { Standard } \\
\text { deviation }\end{array}$ & p value \\
\hline C & 10.1 & 10.1 & 8.1 & 11.3 & 1.3 & \\
E & 17.9 & 18.2 & 9.4 & 26 & 8.3 & 0.393 \\
\hline
\end{tabular}


to untreated animals. This study demonstrated that the dialysis solution induced histological alterations. The thickening and cubic transformation were more pronounced in the peritoneum parietal.

Peritoneal membrane thickening occurred both parietal and visceral, being the thickness increased to 49 days than the 21 days, although not statistically significant difference. The difference between the thicknesses of the parietal and visceral peritoneum was large, which can be due to increased exposure of the parietal peritoneum dialysis solution, because the position of the animal, so the solution of PD gets into closer contact with the ventral wall of the abdomen.

The thickness of the parietal peritoneum was greater in the control group, at 21 and 49 days when compared to experimental group, but without reaching difference statistically significant. This corroborates the found in the literature. Evaluating the degree of fibrosis and adhesion in experimental surgery model was demonstrated a significant reduction in fibrosis, as well as a reduction in the formation of adhesions in the peritoneum, and an increase in activity of t-PA, both in the plasma and the peritoneum, the experimental group. In this study, conducted by Kucuk et al. ${ }^{8}$, mice were used, divided into three groups, a control and two in which simvastatin was used, one with intraperitoneal injection, and the other via force-feeding, on both groups in $0.57 \mathrm{dose} \mathrm{mg} /$ $\mathrm{kg} / \mathrm{dia}$.

Duman et al..$^{9}$ studied the effects of atorvastatin on rats don't urêmicos, also using model of dialysis solution infusion with glucose to $3.86 \%$ in dose of $10 \mathrm{ml} /$ day, for a period of four weeks. Were able to demonstrate that the use of atorvastatin in dose of $80 \mathrm{mg} / \mathrm{L}$ in drinking water, resulted in the preservation of ultrafiltration and in a significant reduction of the thickness of the peritoneum $(52.9 \pm 3.2$ vs $26 \pm 4.4 \mu \mathrm{m}, \mathrm{p}<0.01)$. Similar study was carried out by Yeniçerioglu et al. ${ }^{10}$, in which demonstrated that the use of atorvastatin resulted in less inflammation, fibrosis, vascular proliferation and thickening of the peritoneun.

The findings of the literature, showing the action of statins in several models of fibrosis in other organs, were not reproduced here, although statins have proven anti-inflammatory action. The use of statins in peritoneal fibrosis prevention could be beneficial, because in addition to the anti-inflammatory actions, favoring fibrinolysis in peritoneum, for your action in cells mesoteliais, and the ability to enhance phagocytosis in peritoneal macrophages ${ }^{11}$.

In relation to the number of cells, we have not had any differences between the groups, although the trend has been in the experimental group, with a smaller number of them, at least in the parietal peritoneum. With respect to the amount of collagen, there is no statistically significant differences between the groups, although it was smaller in the parietal peritoneum of the experimental group. There was an increase of collagen, type III in visceral peritoneum to 49 days. This finding should be object of future research. The lack of statistical significance in the findings should not be from the dose of simvastatin administered, because it is similar with used in others experiments ${ }^{12-13}$.

We had significant mortality during the conduct of the study, although only an animal has died by technical problems, in the case, trauma caused by the metal used to force-feeding. The others were the death because, apparently unrelated to the experiment. Deaths cannot be attributed to the use of simvastatin. The high mortality decreased the size of the sample, which may have contributed to not find statistical significance in the analyses made. As the number of the sample was small, there was the impossibility of a proper statistical analysis. More studies with larger sample will be necessary to answer the question.

\section{Conclusion}

The use of simvastatin hasn't changed the intensity of fibrosis

\section{References}

1. Romão Junior JE. Doença renal crônica: definição, epidemiologia e classificação. J Bras Nefrol. 2004;26(3 Supl 1):1-3.

2. Stanley M, CARI. The CARI guidelines. Peritoneal dialysis versus haemodialysis (adult). Nephrology (Carlton). 2010;15(Suppl 1)S2431.

3. Rigby RJ, Hawley CM. Sclerosing peritonites: the experience in Australia. Nephrol Dial Transplant. 1998;13(1):154-9.

4. Brown MC, Simpson K, Kerssens JJ, Mactier RA, and on behalf of the Scottish Renal Registry. Encapsulating peritoneal sclerosis in the new millennium: a national cohort study. Clin J Am Soc Nephrol. 2009;4(7):1222-9.

5. Ishii Y, Sawada T, Shimizu A, Tojimbara T, Nakajima I, Fuchinoue $\mathrm{S}$, Teraoka S. An experimental sclerosing encapsulating peritonitis model in mice. Nephrol Dial Transplant. 2001;16(6):1262-6.

6. Bui DS, Seguro AC, Shimitzu MH, Schliemann I, Martini D, Romão JE, Pecoits Filho RF, Abensur H. N-Acetylcysteine protects the peritoneum from the injury induced by hypertonic dialysis solution. J Nephrol. 2012;25(1):90-5.

7. Vicente PC, Caramori JCT, Franco SRVS, Vicente EJD, Pereira JJ, Santos SMR. Efeito da glicose na histomorfologia do peritônio durante a diálise peritoneal. HU Rev. 2008;34(1):27-31.

8. Kukuk HF, Kaptanoglu L, Kurt N, Uzun H, Eser M, Bingul S, Torlak $\mathrm{OA}$, Akyol $\mathrm{H}$. The role of simvastatin on postoperative peritoneal adesion formation in an animal model. Eur Surg Res. 2007;39(2)98102.

9. Duman S, Sen S, Sözmen EY, Oreopoulos DG. Atorvastatin improves peritoneal sclerosis induced by hypertonic PD solution in rats. Int J Artif Organs. 2005;28(2):170-6.

10. Yeniçerioglu Y, Üzelce Ö, Akar H, Kolatan E, Yilmaz O, Yenisey C, Sarioglu S, Meteoglu I. Effects of atorvastatin on development 
of peritoneal fibrosis in rats on peritoneal dialysis. Ren Fail. 2010;32(9):1095-102.

11. Djaldetti M, Salman H, Bergman M, Bessler H. Effect of pravastatin, simvastatin and atorvastin on de phagocytic activity of mouse peritoneal macrophages. Exp Mol Pathol. 2006;80(2):160-4.

12. Vieira Jr JM, Mantovani E, Rodrigues LT, Dellê H, Noronha IL, Fujihara CK, Zatz R. Simvastatin attenuates renal inflammation, tubular transdifferentiation and interstitial fibrosis in rats with unilateral ureteral obstruction. Nephrol Dial Transplant. 2005;20(8):1582-91.

13. Chade AR, Zhu XY, Grande JP, Krier JD, Lerman A, Lerman LO. Simvastatin abates development of renal fibrosis in experimental renovascular disease. J Hypertens. 2008;26(8):1651-60.

\section{Correspondence:}

Fernando Meyer

Pontifícia Universidade Católica do Paraná (PUCPR)

Departamento de Urologia

Rua Portugal, 307

80510-280 Curitiba - PR Brasil

Tel.: (55 41)3074-7478

Fax: (55 41)3015-0303

fmeyer@onda.com.br

Received: November 10, 2011

Review: January 12, 2012

Accepted: February 14, 2012

Conflict of interest: none

Financial source: none

${ }^{1}$ Research performed at Surgery Postgraduate Program, Pontifical Catholic University of Parana (PUCPR), Curitiba-PR, Brazil. Part of the Master thesis of Gilberto Baroni. 